\title{
The Prospect of Horticultural Organic Farming as Sustainable Agricultural Practice for Reducing Poverty: The Case in Bengkulu City, Indonesia
}

\author{
Teguh Adiprasetyo ${ }^{\#}$, Sukisno ${ }^{\#}$, Nanik Setyowati ${ }^{\#}$, Sempurna Ginting ${ }^{\#}$ and Merakati Handajaningsih ${ }^{\#}$ \\ \# Faculty of Agriculture, University of Bengkulu, Bengkulu, 38122, Indonesia \\ E-mail: teguhadi@yahoo.com,kisno_su@yahoo.com,nanik_srg@yahoo.com,purgint82@yahoo.com,merakati@gmail.com
}

\begin{abstract}
Poverty is still an insistent problem which when confronted by humanity requires a systemic, comprehensive and synchronized approach to alleviate it. The concentration of urban and rural poverty in developing countries underpins the importance of agriculture as a poverty reduction strategy since most of the poor people depend on agriculture. Thus, improving agricultural productivity, competitiveness and sustainability may reduce poverty. This study was intended to (1) find out if sustainable agriculture, i.e., horticultural organic farming practices, could contribute to poverty reduction, (2) identify restrictive factors affecting horticulture organic farming development, and (3) formulate alternative policy intervention for poverty alleviation based on development of organic farming. The respondents were selected using purposive sampling method, comprising of 22 selfclaimed horticultural organic farmers and 22 horticultural conventional farmers. The data were gathered through a structuredquestionnaire and in-depth interview. Descriptive statistics, prospective analyses and analytical hierarchy process were used to analyze the data. The results showed that organic farming practices have potential to increase income of the horticultural farmers. Factors that constrained the development of horticultural organic farming were limited knowledge of organic practices, access to market, financial and risk management services or support. Alternative policy interventions, such as developing a linkage between producers and consumers, strengthening research and development on organic farming, enhancing dissemination knowledge of organic farming practices, and providing access to financial and agriculture management, are proposed.
\end{abstract}

Keywords - poverty; organic farming; horticulture

\section{INTRODUCTION}

Advancement of agricultural technology has been improving rural employment via production of staple food and making agriculture product more affordable. Adoption of higher-yielding varieties and increased use of irrigation and chemical inputs generates growth in productivity. However, this condition causes some farmers to have heavy reliance on chemical fertilizers and pesticides. This intensive production farming system leads to natural resource degradation that slows agricultural productivity. The negative impact on the environment and on human health has also resulted from the heavy dependence of conventional farming on agricultural chemical inputs [1]. Reference [2] pointed out the uncompromising evidence of diminishing returns on harvested products despite the increases of chemical pesticide and fertilizer applied. This evidence is decreasing confidence that these high input technologies will deliver national food security in the next decades. Because of these problems, alternative technological approaches are being advocated, such as organic farming.

According to [3] organic agriculture is a production management system that avoids the use of synthetic fertilizers, pesticides and genetically modified organisms. Moreover, it is intended to enhance and develop healthy agroecosystem, including biodiversity, biological cycles, and soil microbial activities. The emphasis of organic farming is to utilize natural resources efficiently. It maximizes the use of local resources as much as possible. Reference [4] articulates that organic and agro-ecological farming methods are based on the key principles of health, ecology, fairness and care. Organic agriculture should sustain and enhance the health of soil, plant, animal, human and planet as one and be indivisible. It should be based on living ecological systems and cycles, work with them, emulate them and help sustain them. Also, organic farming should build on relationships that ensure fairness with regard to the common environment and life opportunities. And finally, it should be managed in a precautionary and responsible manner to 
protect the health and well-being of current and future generations and the environment. Reference [5] emphasizes that organic agriculture can play an important role towards sustainable utilization of resources in food production, as well as development with less pollution. Organic farming offers a combination of environmentally-sound practices with low external inputs and at the same time contributes to food availability. According to [6], organic farming can support sustainable food security, not only on food availability dimension but also to some degree on food access, stability and utilization since it includes the entire food supply chain, from production and handling to marketing and trade. Reference [7] also noted that organic agriculture can generate significant benefits including economic potential. However, some constraints still remain for developing organic farming such as productivity, standardisation and certification, production technology and market [8].

Organic farming can be expected to contribute economic benefit since it uses primarily organic local resources while avoiding the use of chemicals to increase yields. Rising demand and premium prices for certified organic products may also help farmers increase their income. This economic benefit of organic farming eventually may improve livelihoods of small farmers [9]. A study conducted by [10] on the profitability of vegetable organic agriculture using farm budget-related data showed that organic vegetable yield was smaller than conventional farming, but the revenue was higher due to increased price. However, reference [11] concluded that organically managed crop yields could equal those from conventional agriculture depending on the crop, soil and weather conditions. The net economic return was often equal to or higher than that of conventionally produced crop because organic foods frequently bring higher prices in the marketplace. Although it is not possible to generalize higher revenue for all organic farming practices, it is recognized that ecological organic agriculture can contribute to socio-economic and ecologically sustainable development. This is especially the case in developing countries through increased agricultural productivity and raised income with low cost, locally available technologies and environmentally friendly practices [12]. According to [13], organic farming can have a positive impact on natural systems and human welfare by enhancing diversity of crops and leading to greater livelihood benefits. Overall, the development of organic agriculture may be considered an important and contributing factor for economic development and poverty alleviation.

The present study was intended to find out if horticultural organic farming practices could contribute to poverty reduction through increased income of small urban farmers and to identify restrictive factors affecting horticultural organic farming development. Additionally, the study aimed to formulate alternative policy intervention for poverty alleviation based on development of organic farming.

\section{MATERIALS AND METHODS}

Field survey and data collection of this study was conducted during March to July 2014 in District Gading Cempaka, Bengkulu City, Bengkulu Province, Indonesia. This district was selected because of the only location of self-claimed horticultural organic farming. Respondents of this study were farmers and experts. The farmer respondents were selected using purposive sampling method, comprising of 22 self-claimed horticultural organic farmers and 22 horticultural conventional farmers. The data were gathered through a structured-questionaire and in-depth interview to acquire information on revenue and cost of farming and to reveal organic farming constraints affecting horticultural organic farming development. Descriptive statistics were used to analyze the data.

Inventory of constraints then was evaluated based on 5 expert judgements using prospective analyses to determine the leverage factor of contraints. Alternative policy interventions were developed based on the leverage factors. According to [14], steps of prospective analyses were: (1) Identifying of variables that might have an influence on the evolution of the system. The objective of this step was to establish a list of variables through structure-quesionaire based on free expression of individual farmer opinion. (2) After having lists of variables, analyzing mutual influence of variables based on expert judgement. Experts were requested to examine the direct influence of each variable on the others. The examination was based on the assessment value scale of 0 to 3 as shown in Table 1. (3) Interpreting the graph and the type of the variables. The influence-dependence graph, as shown in Figure 1 displayed how the variables were scattered in a four-quadrant space delimited by two axes [15]. The graph was based on the weighted influence-dependence value of each variable calculated from the influence score of each variable on the others. Each quadrant in the graph corresponded to specific characteristics of the variables. The upper-left quadrant was the area of the independent variables (input variables) where most influent and independent variables were present. The upper-right quadrant matched with linkage variables (stake variables). Variables in this quadrant had strong influence and dependence to the system. The lower-right quadrant corresponded to the dependent variables (output variables). Autonomous variables (unused vaiables) were found in the lower-left quadrant. (4) Formulating alternative policy interventions was constructed based on dependent variables and/or linkage variables.

TABLE I

ASSESMENT VALUE OF INFLUENCE BETWEEN FACTORS

\begin{tabular}{|c|l|}
\hline Score & \multicolumn{1}{c|}{ Description } \\
\hline 0 & No influence between factors \\
\hline 1 & Small influence \\
\hline 2 & Medium influence \\
\hline 3 & Strong influence \\
\hline
\end{tabular}

Alternative policy interventions for poverty reduction based on development of organic farming were then prioritized using Analyical Hierarchy Process (AHP) as explained by [16]. According to [16] the Analytical Hierarchy Process is a theory of measurement through pairwise comparisons and relies on the judgements of experts to obtain priority scales. In order to generate priorities of alternative policy interventions, steps of AHP were: (1) Defining the goal and determine the kind of knowledge sought. In this case the goal was development of organic farming for poverty reduction. (2) Structuring the 
decision hierarchy from the top with the goal of the decision, then the criteria which were the leverage factors of contraints to the lowest level which were the alternative policy interventions. (3) Constructing a set of pairwise comparison matrices. Each element in an upper level was used to compare the elements in the level immediately below with respect to it. Comparison was performed using scale 1 (equally importance) to 9 (extremely importance). (4) Using the priorities obtained from the comparisons to weigh the priorities in the level immediately below. Weighting was performed for every element. Then for each element in the level below add its weighted values and obtain its overall or global priority.

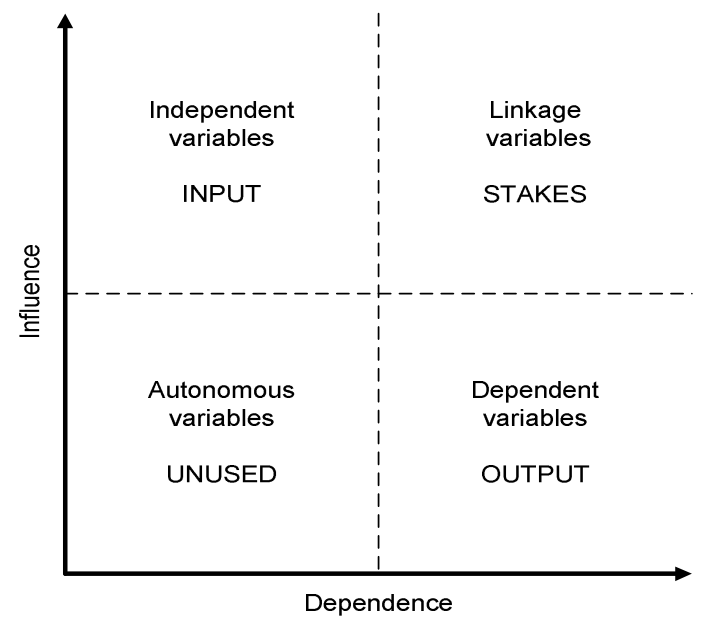

Fig. 1 The diagram of influence-dependence level of factors

\section{RESULTS AND DISCUSSIONS}

The results relating to the total cost and revenue per hectare of morning glory (Ipomoea aquatica), amaranth (Amaranthus hybridus), and mustard green (Brassica juncea) are presented in Table 2 . The vegetables are planted in the plots of 30 to $50 \mathrm{~m} 2$ and sold in bundles, but reported in hectare and kilogram. Overall, the study showed that conventional farming still outperformed self-claimed organic farming with respect to yield, production cost and total revenue, but not to net profit. The production of morning glory, amaranth and mustard green grown organically tended to be lower than that by conventional methods. Production technology of self-claimed organic farming was similar to conventional farming, except self-claimed organic farming excluded the use of synthetic agrochemical such as urea and pesticide. Without using synthetic agrochemicals, the production of the vegetables decreased. The gap in production between these two farming practices was highest for mustard green $(16.7 \%)$ and lowest for amaranth $(11.5 \%)$. Since the price of the vegetable product was the same, the revenue of morning glory, amaranth and mustard green grown organically also tended to be lower than that grown conventionally. The gap in revenue was highest for mustard green and lowest for amaranth.

Self-claimed organic farming increased the net profit in morning glory and amaranth production. The increase was contributed by a decrease in total production cost. Production cost of self-claimed organic farming was decreased by $19.4 \%$ for morning glory, $18.9 \%$ for amaranth and $22.6 \%$ for mustard green compared to conventional farming. The increase of net profit was $4.9 \%$ for morning glory and $3.3 \%$ for amaranth. However, net profit declined in mustard green by $12.3 \%$. These differences show the mixed impacts of organic farming practice on net profit strongly suggesting that net profit was crop specific. Mustard green as observed in the field was more vulnerable to pest attack than morning glory and amaranth. Consequently, the yield of mustard green tended to be lower in organic farming practice as compared to conventional farming.

Although the price of morning glory and amaranth of selfclaimed organic farming was the same as the price of conventional farming, the net profit was higher for organic farming practice, especially for morning glory and amaranth. This finding indicated that organic farming has potential to increase income of horticultural small farmers, and thus, it can contribute to poverty reduction. The potential in reduction may even be higher if consumer awareness about organic food was campaigned. Moreover, it also had another benefit that was not calculated in this study, such as decreased health risk related to pesticide use.

TABLE II

BUDGET OF VEGETABLE FARMING PER CYCLE

\begin{tabular}{|l|r|r|}
\hline \multicolumn{1}{|c|}{ Commodity/Item } & \multicolumn{1}{|c|}{$\begin{array}{c}\text { Self-claimed } \\
\text { organic farming }\end{array}$} & $\begin{array}{c}\text { Conventional } \\
\text { farming }\end{array}$ \\
\hline Morning glory: & 22.500 & 25.000 \\
Output (kg/ha) & 3.200 & 3.200 \\
Price (rupiah/kg) & 72.000 .000 & 80.000 .000 \\
Total revenue (Rp/ha) & 39.455 .000 & 48.975 .000 \\
Total cost (Rp/ha) & 32.545 .000 & 31.025 .000 \\
Net profit (Rp/ha) & & \\
\hline Amaranth: & 23.500 & 26.000 \\
Output (kg/ha) & 3.330 & 3.330 \\
Price (rupiah/kg) & 78.330 .000 & 86.667 .000 \\
Total revenue (Rp/ha) & 40.855 .000 & 50.375 .000 \\
Total cost (Rp/ha) & 37.475 .000 & 36.292 .000 \\
Net profit (Rp/ha) & & \\
\hline Mustard green: & 22.500 & 27.000 \\
Output (kg/ha) & 3.700 & 3.700 \\
Price (rupiah/kg) & 83.330 .000 & 100.000 .000 \\
Total revenue (Rp/ha) & 32.515 .000 & 42.035 .000 \\
Total cost (Rp/ha) & 50.815 .000 & 57.965 .000 \\
Net profit (Rp/ha) & &
\end{tabular}

Constraints identified relating to horticultural organic farming development were production standard, knowledge of organic farming, production input, availability of technical support, financial support, market access, capital, training and education opportunity for farmers, product price, infrastructures, risk management, certification cost, organic seed, perception of organic farming and promotion. The results of the prospective analyses are presented in Figure 2. Based on the analyses, knowledge, market access, financial support and risk management were the most influent and dependent variables or the leverage factor of constraints. This suggests that alternative policy interventions for poverty reduction based on development of organic farming should be in the area of these variables to improve the effectiveness of the programs. 


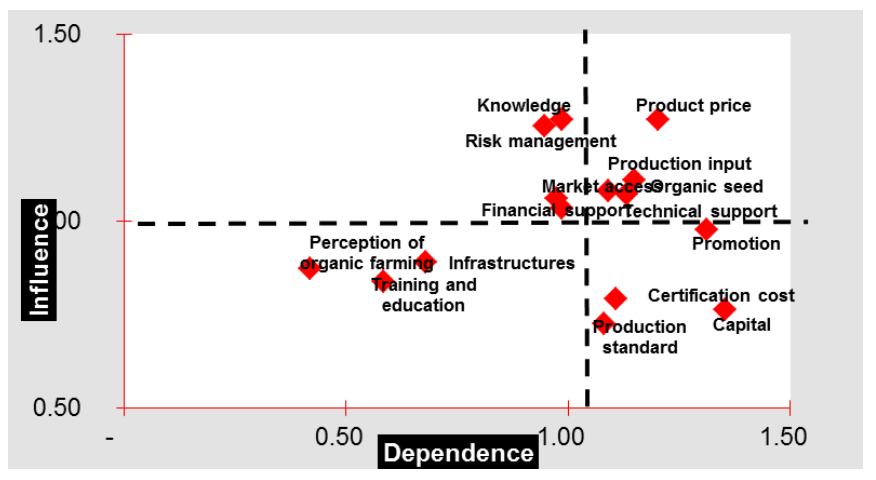

Fig. 2 The importance's level of variables influencing the development of organic farming

In-depth interview with experts came up with four alternative policy interventions: (1) providing access to financial and agriculture management, (2) enhancing dissemination of knowledge on organic farming practices, (3) developing linkage between producers and consumers, and (4) strengthening research and development on organic farming. These four alternatives were then prioritized in order to achieve the goal for the development of horticultural organic farming to reduce poverty based on the criteria of financial support, knowledge, market access and risk management. The results of AHP analyses are shown in Figure 3. Alternative policy interventions according to priority are developing linkage between producers and consumers, strengthening research and development on organic farming, enhancing dissemination knowledge of organic farming practices, and providing access to financial and agriculture management.

The first priority of intervention is developing linkage between producers and consumers. This kind of linkage can be established through community supported agriculture (CSA). CSA is an alternative marketing method that creates a close connection between farmer and consumer. From its inception, CSA may bring mutual benefits since it is reconnecting farmers to consumers, supporting small farms by providing advance financing and spreading financial risk, and providing healthy food using primarily organic methods of production. In addition, consumers get benefits associated with receiving fresh and healthy produce at affordable prices. Farmers also earn a better price by selling the produce directly to the customers. This type of arrangement may produce benefits that extend beyond the use of organic growing practices, since CSA incorporates social justice and community development by helping low-income people and running education activities [17].

Knowledge is one of the key factors affecting the development of organic farming. Therefore, strengthening research and development on organic farming would help build practical knowledge on organic farming. Combining local knowledge and modern technologies is needed in order to respond to the requirements of agricultural production and environmental conditions. Example of practices based on local knowledge is the use of botanical pesticides, such as neem and marigolds to prevent insect outbreaks. Once the knowledge has been developed, dissemination efforts have to be enhanced.

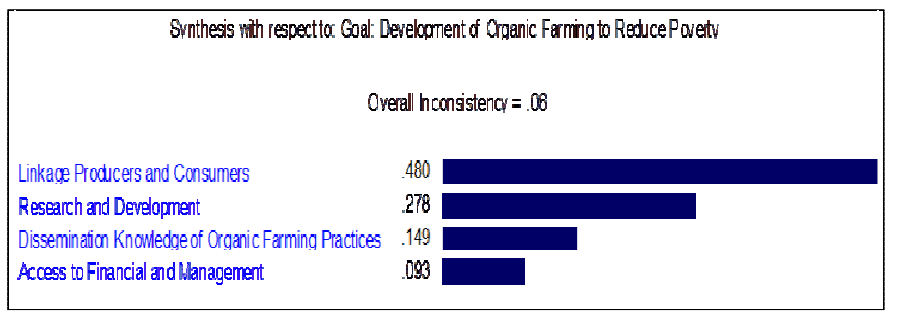

Fig. 3 Priorities of four alternative policy interventions

\section{CONCLUSIONS}

Organic farming practices have potential to increase the income of the horticultural farmers. Factors that constrained the development of horticultural organic farming were limited knowledge of organic practices, access to market, financial and risk management services or support. This study also proposed alternative policy interventions which are developing linkage between producers and consumers, strengthening research and development on organic farming, enhancing dissemination knowledge of organic farming practices, and providing access to financial and agriculture management.

\section{ACKNOWLEDGMENT}

We would like to thank experts and students of organic farming class for involvement and supporting this research.

\section{REFERENCES}

[1] N. A. Tiraieyari, A. Hamzah, and B.A. Samah, "Organic farming and sustainable agriculture in Malaysia: organic farmers' challenges towards adoption", Asian Sosial Science, vol. 10, pp. 1-7, 2014.

[2] N.E.H. Scialabba, "Organic agriculture and food security", Italy, FAO: International Conference on Organic Agriculture and Food Security, 3-5 May 2007.

[3] Codex Alimentarius Commission, "Guideline for the production, processing, labelling and marketing of organically produced foods", Italy, Rome, Joint Food and Agriculture Organization Organization (FAO) and World Health Organization (WHO) Food Standards Program, 2007, [Online]. Available: http://www.codexalimen tarius.net/download/standards/360/ cgx_032e.pdf

[4] IFOAM [International Federation of Organic Agriculture Movements], Principles of Organic Agriculture - Preamble, 2005, [Online]. Available: http://www.ifoam.org/sites/default/files/ ifoam_poa.pdf

[5] S.B. Aher, S. Bhaveshananda, and B. Sengupta, "Organic agriculture: way towards sustainable development", International Journal of Environmental Sciences vol.3, pp. 209-216, 2012.

[6] M. Vaarst, "Organic farming as a development strategy: who are interested and who are not?", Journal of Sustainable Development, vol. 3, pp. 38-50, 2010.

[7] E. Kerselaers, W. Govaerts, L. Lauwers, L. De Cock, and G. van Huylenbroeck, "Modelling farm level economic potential for conversion to organic farming", Denmark, Copenhagen: The XIth European Association of Agricultural Economists Conggress "The Future of Rural Europe in the Global Agri-Food System", August 24-27-2005.

[8] D. Rigby and D. Cáreres, "Organic farming and the sustainability of agricultural systems", Agricultural Systems, vol. 68, pp. 21-40, 2001.

[9] M. Bennett and S. Franzel, "Can organic and resource-conserving agriculture improve livelihoods? A synthesis", International Journal of Agricultural Sustainability vol. 11, pp. 193-215, 2013.

[10] S. Rani, M. A. Khan, H. Shah, and A. S. Anjum, "Profitability analysis of organic cauliflower, radish and turnip produce at National Agriculture Research Centre, Islamabad, Pakistan", Asian Journal of Agriculture and Rural Development, vol. 3, pp. 929-935, 2013.

[11] D. Pimentel, P. Hepperly, J. Hanson, D. Douds, and R. Seidel, "Environmental, energetic, and economic comparisons of organic 
and conventional farming systems", Bioscience vol.55, pp. 573-582, 2005.

[12] D.M. Amudavi, A.O. Nkurumwa, and J.M. Ombati, M. Ngigi, "Technical, economic and social gaps and information needs among smallholder farmers in practice of ecological organic agriculture in Kenya", International Journal of Agriculture Innovation and Research vol 3, pp. 198-209, 2014.

[13] P. Bakewell-Stone, G. Lieblein, and C. Francis, "Potentials for organic agriculture to sustain livelihoods in Tanzania", International Journal of Agricultural Sustainability vol. 6, pp. 22-36, 2008.
[14] R. Bourgeois and F. Jesus, "Participatory Prospective Analysis: Exploring and Anticipating Challenges with Stakeholders", United Nation, CAPSA Monograph No.46, 2004.

[15] H. Hardjomidjojo, Metode Analisis Prospektif, Bogor, IPB, Departemen Teknologi Industri Pertanian, Fakultas Teknologi Pertanian, 2002.

[16] T.L. Saaty, "Decision making with the analytical hierarchy process", International Journal of Services Sciences, vol. 1, pp. 83-98, 2008.

[17] S. Patel, and R. MacRae, "Community supported agriculture in the city: the case of Toronto", Journal of Agriculture, Food Systems, and Community Development. Advance online publication, 2012, [Online]. Available: http://dx.doi.org/105304/jafscd2012024003. 